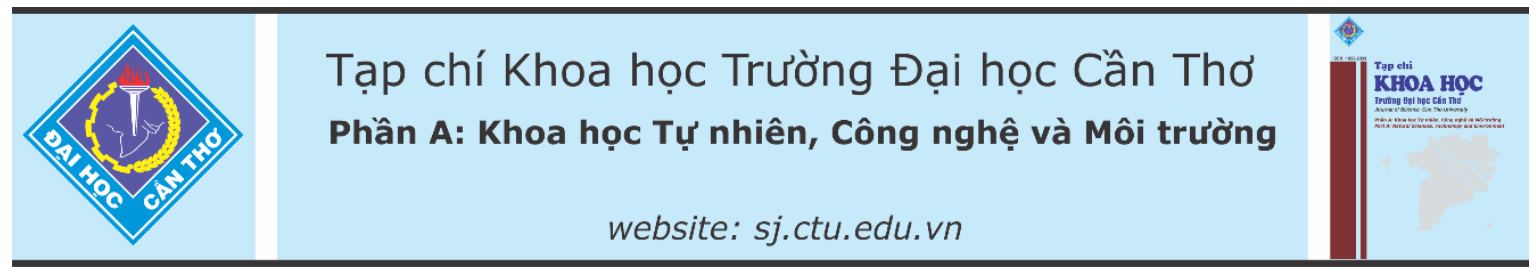

DOI:10.22144/ctu.jvn.2021.086

\title{
ĐA DẠNG HỌ LAN (ORCHIDACEAE) Ở NAM BỘ VỚI GHI NHẬN MỚI MỘT LOÀI THUỘC CHI Dendrobium CHO HỆ THỤC VẬT VIẸTT NAM
}

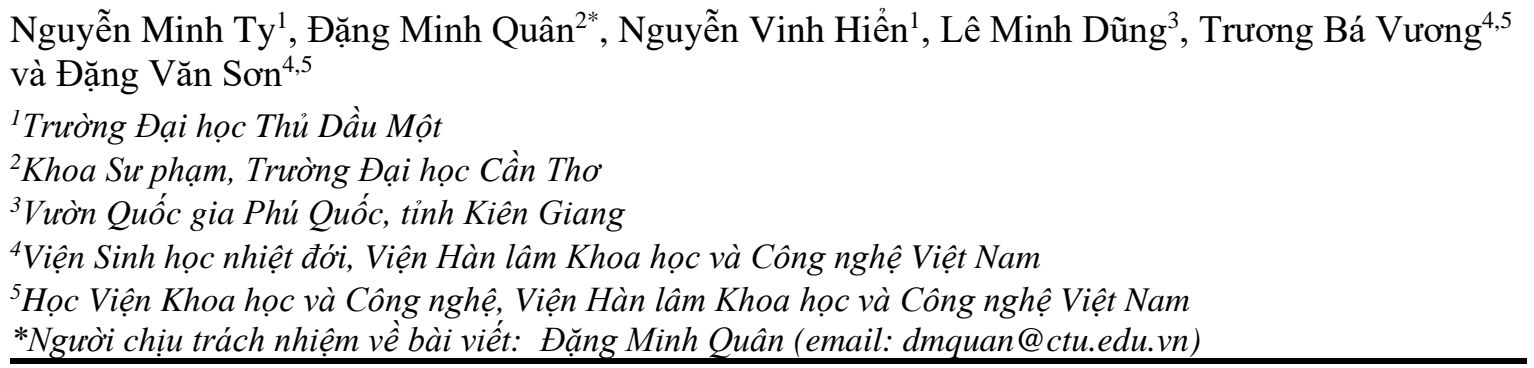

\section{Thông tin chung:}

Ngày nhận bài: $28 / 01 / 2021$

Ngày nhận bài sủa: 03/04/2021

Ngày duyệt đăng: 25/06/2021

Title:

Diversity of Orchidaceae from Southern Viet Nam with one new record of genus

Dendrobium for the flora of Viet Nam

\section{Tù khóa:}

Ghi nhận mói, họ Lan, Hoàng thảo indragiri, Nam Bộ

\section{Keywords:}

Dendrobium indragiriense, new record, Orchidaceae, Southern Vietnam

\begin{abstract}
A study on the diversity of Orchids in the Southern Viet Nam was conducted in 2018 and 2019 to assess the diversity of orchid species composition in this region. The methods were used including field investigation and sampling methods, morphological comparison method combined with looking up specialized documents on the Orchidaceae. The study results identified 324 species belonging to 84 genera. Among them, all species were used as ornamental plants; 22 species were used for medicinal herbs; and 10 species were listed for conservation in Viet Nam Red Data Book, Part II, Plants (2007); 324 species in the Decree 06/2019/ND-CP of the Government; 324 species in CITES. The life forms of Orchids were divided into groups including (1) epiphytes with 247 species, (2) terrestrials with 60 species, (3) saprophytes with 4 species, (4) lithophytes anh epiphytes with 8 species, (5) epiphytes and terrestrials with 3 species, and (6) epiphytes and terrestrials with 2 species. Specifically, Dendrobium indragiriense Schltr. is a new record for the flora of Viet Nam, and 64 species were added to the Southern Viet Nam.
\end{abstract}

\section{TÓM TÁT}

Nghiên cứu đa dạng ho Lan (Orchidaceae) ở Nam Bộ đuoọc thực hiện trong hai năm 2018 và 2019 nhằm muc tiêu đánh giá được thưc trạng đa dạng thành phần loài lan ở vùng này. Các phương pháp được sủ dụng bao gồm: phương pháp điều tra thực địa và thu mẫu, phuơng pháp so sánh hình thái kết hơp với tra cứu các tài liệu chuyên ngành về ho Lan. Kết quả nghiên cứu đã xác định được ho Lan ở vùng nghiên cứu có 324 loài thuộc 84 chi. Trong đó, tất cả các loài đều có giá trị làm cảnh, 22 loài làm thuốc và 10 loài nằm trong Sách đỏ Việt Nam (2007), 324 loài trong Nghị định 06/2019/ND-CP của Chính phủ và 324 loài trong danh luc của CITES. Dạng sống của các loài lan cũng được ghi nhận, bao gồm: 247 loài Phong lan (Epi); 60 loài Địa lan (Ter); 4 loài Lan hoại sinh (Sap); 8 loài vùa Thach lan (Lit) và Phong lan (Epi), 3 loài vùa Thạch lan (Lit) và Địa lan (Ter), 2 loài vùa Phong lan (Epi) và Địa lan (Ter). Đặc biệt, ghi nhận mói 1 loài là Hoàng thảo indragiri (Dendrobium indragiriense Schltr.) cho hệ thưc vật Việt Nam và bổ sung 64 loài cho hệ thực vật Nam Bộ. 


\section{MỞ ĐẦU}

Nam Bộ là phần đất tận cùng ở phía nam Việt Nam, kéo dài từ phía nam của dãy Trường Sơn đến tận mũi của bán đảo Cà Mau, có tổng diện tích $63.487,85 \mathrm{~km}^{2}$, có đơn vị hành chính gồm 2 thành phố và 17 tỉnh là Bà Rịa - Vũng Tàu, Đồng Nai, Bình Phước, Bình Dương, Tây Ninh, Thành phố Hồ Chí Minh, Long An, Bến Tre, Tiền Giang, Vĩnh Long, Đồng Tháp, Thành phố Cần Thơ, Hậu Giang, An Giang, Sóc Trăng, Trà Vinh, Bạc Liêu, Kiên Giang và Cà Mau (Sterling et al., 2007; Đặng Văn Sơn, 2012). Các sinh cảnh đặc trưng ở Nam Bộ là rừng đầm lầy nước ngọt, rừng ngập mặn, đồng cỏ, rừng thường xanh và rừng rụng lá, với hệ động thực vật khá đa dạng và phong phú, trong đó có các loài lan rừng. Các nghiên cứu và ghi nhận về lan ở Nam Bộ đã được thực hiện ở các Vườn Quốc gia và Khu Bảo tồn thiên nhiên như: Vườn Quốc gia Cát Tiên có 116 loài thuộc 43 chi (Phân viện điều tra quy hoạch rừng Nam Bộ [SubFIPI], 2010), Vườn Quốc gia Bù Gia Mập có 46 loài thuộc 20 chi (Viện Sinh học nhiệt đới [ITB], 2010a), Vườn Quốc gia Lò Gò - Xa Mát có 28 loài thuộc 19 chi (ITB, 2010b), Vườn Quốc gia Côn Đảo có 18 loài thuộc 15 chi (Lê Xuân Ái \& Trần Định Huệ, 2013), Vườn Quốc gia Phú Quốc có 125 loài thuộc 59 chi (Đặng Văn Sơn và ctv., 2017), Khu Bảo tồn thiên nhiên Vĩnh Cửu có 60 loài thuộc 28 chi (SubFIPI, 2009), Khu Bảo tồn thiên nhiên Bình Châu - Phước Bửu có 28 loài thuộc 22 chi (Lưu Hồng Trường và ctv., 2012), tuy nhiên các nghiên cứu này thiếu mẫu nghiên cứu, còn sai sót về danh pháp và nhiều loài chưa được cập nhật. Trong khi đó, Nam Bộ được xem là nơi bảo tồn các loài lan quý hiếm, đặc hữu và có giá trị kinh tế cao cho khu vực phía nam Việt Nam. Do vậy, việc điều tra, cập nhật cơ sở dữ liệu về tính đa dạng các loài thuộc họ Lan (Orchidaceae) cho Nam Bộ là một trong những nhiệm vụ rất quan trọng, giúp các nhà quản lý có chiến lược bảo tồn nguồn tài nguyên thiên nhiên nói chung và nguồn gene của các loài thuộc họ Lan nói riêng nhằm phục vụ công tác phát triển kinh tế xã hội ở Nam Bộ là cần thết.

\section{NGUYÊN LIỆU VÀ PHƯƠNG PHÁP NGHIÊN CÚU}

\subsection{Nguyên liệu}

Các loài thuộc họ Lan (Orchidaceae) được điều tra và thu thập ở Nam Bộ, Việt Nam.

\subsection{Phương pháp nghiên cứu}

Tiến hành điều tra và thu mẫu các loài thuộc họ Lan (Orchidaceae) ngoài thực địa, địa điểm điều tra được thiết lập dựa vào đặc điểm phân bố của họ Lan (Orchidaceae), trong đó ưu tiên điều tra ở các Vườn
Quốc gia, Khu Bảo tồn thiên nhiên và rừng đặc dụng như: Vườn Quốc gia Cát Tiên, Khu Bảo tồn thiên nhiên Vĩnh Cửu và rừng đặc dụng Tân Phú thuộc tỉnh Đồng Nai, Vườn Quốc gia Bù Gia Mập và rừng đặc dụng Bù Đăng thuộc tỉnh Bình Phước, Vườn Quốc gia Lò Gò - Xa Mát thuộc tỉnh Tây Ninh, Vườn Quốc gia Côn Đảo và Khu Bảo tồn thiên nhiên Bình Châu - Phước Bửu thuộc tỉnh Bà Rịa - Vũng Tàu, Vườn Quốc gia Phú Quốc thuộc tỉnh Kiên Giang, rừng đặc dụng Núi Cấm thuộc tỉnh An Giang. Việc điều tra thu thập mẫu được tiến hành theo các tuyến vạch sẵn dựa vào bản đồ hiện trạng rừng ở địa điểm khảo sát, trong đó ưu tiên các tuyến phải đại diện và thông qua các sinh cảnh khác nhau, mỗi tuyến khảo sát cứ $10 \mathrm{~m}$ tỏa ra hai bên để thu mẫu, thời gian điều tra được thực hiện 16 đợt, mỗi đợt từ 7-10 ngày (từ tháng $6 / 2018$ đến tháng 12/2019). Có tổng số 500 mẫu lan được thu thập trong quá điều tra gồm bộ mẫu sống và bộ mẫu khô/ngâm, được xử lý và chụp ảnh ngoài thực địa, và kèm theo lý lịch mẫu. Bộ mẫu sống được lưu giữ ở Vườn sưu tập lan của Trường Đại học Thủ Dầu Một và bộ mẫu khô/ngâm được lưu giữ ở Bảo tàng động thực vật thuộc Viện Sinh học nhiệt đới, Viện Hàn lâm Khoa học và Công nghệ Việt Nam.

Tên khoa học và dạng sống của các loài thuộc họ Lan được xác định theo phương pháp hình thái so sánh trên cơ sở các tài liệu công bố của Averyanov et al. (2003), Averyanov (2013), Cribb (1998), Dương Đức Huyến (2007), Gagnepain and Guillaumin (1932-1934), Nguyễn Tiến Bân và ctv. (2005) và Phạm Hoàng Hộ (2003), đồng thời đối chiếu so mẫu với bộ mẫu chuẩn được lưu giữ ở Bảo tàng thực vật thuộc Viện Sinh học nhiệt đới. Việc chỉnh sửa và cập nhật tên khoa học các loài thuộc họ Lan được tiến hành theo các công bố của Kew science (https://wcsp.science.kew.org) và The Plant List (2013) (http://www.theplantlist.org/).

Giá trị sử dụng của các loài thuộc họ Lan (Orchidaceae) được xác định dựa theo phương pháp phỏng vấn có sự tham gia của cộng đồng (PRA) và các tài liệu có liên quan như: Võ Văn Chi (2012), Phạm Hoàng Hộ (2006), Trần Hợp (1998), Đỗ Tất Lợi (2009), Nguyễn Thiện Tịch (2001). Tình trạng bảo tồn của các loài thuộc họ Lan được đánh giá theo Sách đỏ Việt Nam - Phần thực vật (Bộ Khoa học và Công nghệ, 2007), CITES (2019) và Nghị định 06/2019/NĐ-CP (Chính phủ Việt Nam, 2019).

\section{KẾT QUẢ VÀ THẢO LUẬN}

\subsection{Ghi nhận mới một loài thuộc chi Dendrobium cho hệ thực vật Việt Nam}

Tên Việt Nam: Hoàng thảo indragiri 
Tên khoa họ: Dendrobium indragiriense Schltr., Repert. Spec. Nov. Regni Veg. 9: 164. 1911. - Grastidium indragiriense (Schltr.) Rauschert, Feddes Repert. 94: 450. 1983; - Dendrobium isomerum Schltr., Beibl. Bot. Jahrb. Syst. 104: 35. 1911; - Dendrobium inconspicuiflorum J.J.Sm.,
Bull. Jard. Bot. Buitenzorg, sér. 2, 25: 42. 1917; Grastidium isomerum (Schltr.) Rauschert, Feddes Repert. 94: 450. 1983; - Grastidium inconspicuiflorum (J.J.Sm.) M.A.Clem. \& D.L.Jones, Lasianthera 1: 84. 1997 (Hình 1. A-C).

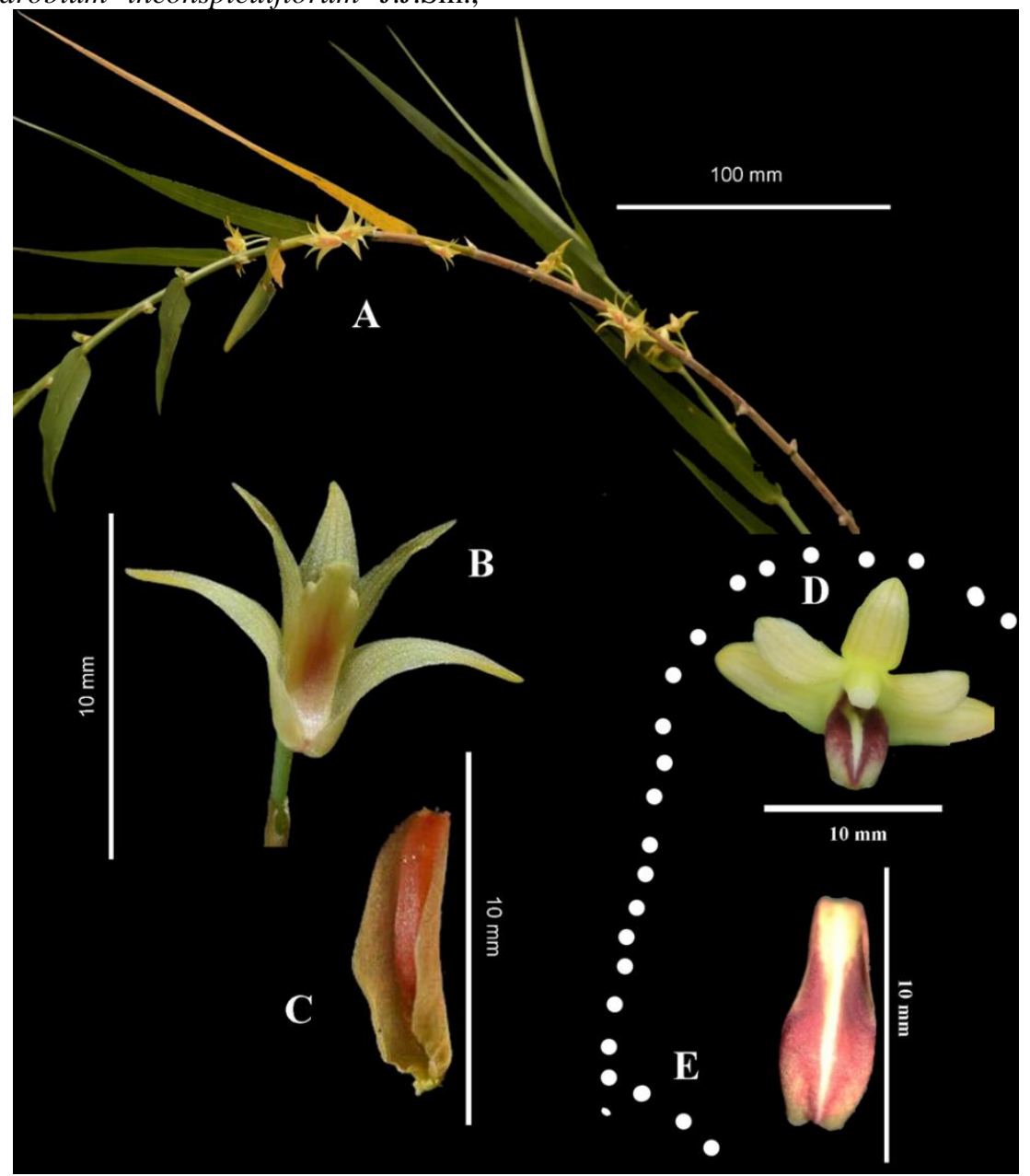

Hình 1. Dendrobium indragiriense Schltr.

(A-C): (A) Thân mang hoa, (B) Hoa, (C) Môi hoa vói thể chai màu cam (ảnh chụp bởi Lê Minh Dũng); Dendrobium salaccense (Blume) Lindl. (D-E): (D) Hoa, (E) Môi hoa (ảnh chup bởi Truóng Bá Vuơng).

Mô tả: Cây phụ sinh; thân mảnh, dài đến $1 \mathrm{~m}$. Lá mọc cách thành hai hàng dọc theo thân, phiến lá dài, hẹp, kích thước 10-13 × 0,5-0,8 cm, đầu nhọn. Hoa mọc ở thân, thường từ 1-2 hoa trên một phát hoa; cuống dài khoảng $5 \mathrm{~mm}$. Hoa màu vàng nhạt, môi có thể chai màu cam; lá đài giữa và bên giống nhau về kích thước, dài khoảng $7 \mathrm{~mm}$, rộng khoảng 2,5 $\mathrm{mm}$, lá đài giữa hình trứng hẹp có 3 vân, hai lá đài bên rộng hơn ở gốc, mọc xéo ra hai bên, đầu nhọn; cánh hoa mọc hơi xéo ra hai bên, hẹp hơn so với lá đài giữa, dài khoảng $6,5 \mathrm{~mm}$, rộng khoảng $2 \mathrm{~mm}$, đầu nhọn; môi hoa không phân thùy, dài khoảng 7,5 mm, phần trước cong ra ngoài, mặt trên môi từ gốc có một mảng thể chai lớn, trơn, không lông, gần như che phủ hết mặt trong môi, kéo dài lên gần đầu môi rồi dừng lại, tại điểm dừng có 3 hàng lông thưa chạy dọc tới đầu môi, phần rìa của đầu môi uốn lượn. Cột phấn có hai cánh nhỏ tròn; nắp phấn và phấn hoa không ghi nhận được.

Sinh hoc và sinh thái: Cây mọc phụ sinh ở rừng thường xanh ven suối ở độ cao $450 \mathrm{~m}$ ở Vườn Quốc gia Phú Quốc, tỉnh Kiên Giang. Mùa hoa vào tháng 4. 
Mẫu chuẩn: Sumatra, Indrairi district, Lalah River, 04 May 1901, Schlechter 13277 (holotype B).

Phân bố: Mới chỉ tìm thấy ở Vườn Quốc gia Phú Quốc thuộc tỉnh Kiên Giang, phía Nam Việt Nam. Ngoài ra, còn ghi nhận ở Ấn Độ, Thái Lan, Indonesia và Malaysia (Karthigeyan et al., 2014).

Mẫu nghiên cứu: Việt Nam, tỉnh Kiên Giang, Vườn Quốc gia Phú Quốc, độ cao $450 \mathrm{~m}$, ngày 18 tháng 11 năm 2019, Lê Minh Dũng, Truoong Bá Vuơng, PQ100 (VNM - Bảo tàng động thực vật, Viện Sinh học nhiệt đới).

Ghi chú: Hoàng thảo Indragiri là loài ghi nhận mới cho hệ thực vật Việt Nam và được phát hiện ở
Vườn Quốc gia Phú Quốc, tỉnh Kiên Giang. Loài này có đặc điểm gần giống với loài Dendrobium salaccense (B1.) Lindl. (Hình 1. D-E) về dạng thân, lá và hoa, nhưng khác với loài $D$. salaccense bởi ở môi hoa là thể chai kéo dài từ gốc đến đầu môi, trong khi đó loài $D$. salaccense không có thể chai.

\section{2. Đa dạng thành phần loài}

Kết quả phân tích số liệu thu được ngoài thực địa và trong phòng thí nghiệm, đã xác định được họ Lan (Orchidaceae) ở Nam Bộ có 324 loài thuộc 84 chi, trong đó bổ sung cho Nam Bộ 64 loài (bao gồm 1 ghi nhận mới cho Việt Nam) so với các nghiên cứu trước đó Bảng 1).

Bảng 1. Danh sách các loài thuộc họ Lan (Orchidaceae) bổ sung

\begin{tabular}{|c|c|c|c|}
\hline STT & Tên Khoa học & Tên Việt Nam & Dạng sống \\
\hline 1 & Acampe papillosa Lindl. & Bắp ngô cụm ngắn & Epi \\
\hline 2 & Agrostophyllum callosum Rchb.f. & Càng cua thân dài & Epi \\
\hline 3 & Appendicula floribunda (Schltr.) Schltr. & Vệ lan nhiều hoa & Lit, Epi \\
\hline 4 & Brachypeza laotica (Seidenf.) Seidenf. & Lan môi sừng & Epi \\
\hline 5 & Bulbophyllum affine Wall. ex Lindl. & Cầu điệp gối & Epi \\
\hline 6 & Bulbophyllum ayuthayense J.J.Verm., Schuit. \& de Vogel & Lan củ chén xiêm & Epi \\
\hline 7 & Bulbophyllum blepharistes Rachb.f. & Lọng tai thỏ & Epi \\
\hline 8 & Bulbophyllum disciflorum Rolfe & Ba góc đĩa & Epi \\
\hline 9 & Bulbophyllum dissitiflorum Seidenf & Lọng chùm cong & Epi \\
\hline 10 & Bulbophyllum haniffii Carr & Lọng chân rết & Epi \\
\hline 11 & Bulbophyllum physocoryphum Seidenf. & Cầu diệp & Epi \\
\hline 12 & Bulbophyllum tenuifolium (Blume) Lindl. & Cầu diệp lá nhỏ & Epi \\
\hline 13 & Bulbophyllum wallichii Rchb.f. & Cầu diệp wallich & Epi \\
\hline 14 & Calanthe angustifolia (Blume) Lindl. & Bầu rượu kim tân & Ter \\
\hline 15 & Calanthe clavata Lindl. & Bầu rượu chùy & Ter \\
\hline 16 & Callostylis rigida Blume & Nỉ lan biến màu & Ter \\
\hline 17 & Cleisostoma arietinum (Rchb.f.) Garay & Mật khẩu đầu bò & Epi \\
\hline 18 & Cleisostoma fuerstenbergianum Kraenzl. & Mật khẩu mành & Epi \\
\hline 19 & Cleisostoma lecongkietii Tich et Aver & Mật khẩu lê công kiệt & Epi \\
\hline 20 & Cleisostoma simondii (Gagnepain) Seidenfaden & Mật khẩu môi nhọn & Epi \\
\hline 21 & Coelogyne assamica Linden \& Rchb.f. & Thanh đạm cánh bướm & Epi \\
\hline 22 & Coelogyne fimbriata Lindl. & Thanh đạm rìa & Epi \\
\hline 23 & Coelogyne moorena Rolfe & Thanh đạm tuyết ngọc & Epi \\
\hline 24 & Coelogyne sanderae Kraenzl. ex O'Brien & Thanh đạm cảnh & Epi \\
\hline 25 & Crepidium purpureum (Lindl.) Szlach. & Mai đất tím & Ter \\
\hline 26 & Cymbidium bicolor Lindl. & Đoản kiếm hai mầu & Ter \\
\hline 27 & Cymbidium erythrostylum Rolfe. & Bạc lan & Ter \\
\hline 28 & Dendrobium anosmum Lindl. & Phi điệp & Epi \\
\hline 29 & Dendrobium capillipes Rchb.f. & Kim điệp & Epi \\
\hline 30 & Dendrobium cumulatum Lindl. & Hoàng thảo tích tụ & Epi \\
\hline 31 & Dendrobium ellipsophyllum T.Tang \& F.T.Wang & Hoàng thảo hương duyên & Epi \\
\hline 32 & Dendrobium indragiriense Schltr.* & Hoàng thảo indragiri & Epi \\
\hline 33 & Dendrobium macrostachyum Lindl. & Từ ngọc & Epi \\
\hline 34 & Dendrobium parciflorum Rchb.f. ex Lindl. & Hoàng thảo hương lan & Epi \\
\hline 35 & Dendrobium simondii Gangnep. & Hoàng thảo simond & Epi \\
\hline 36 & Dendrobium uniflorum Griff. & Hoàng thảo nhất hoa & Epi \\
\hline 37 & Gastrochilus yunnanensis Schltr. & Hàm lân vân nam & Epi \\
\hline
\end{tabular}




\begin{tabular}{|c|c|c|c|}
\hline STT & Tên Khoa học & Tên Việt Nam & Dạng sống \\
\hline 38 & Liparis nana Rolfe & Tai dê lùn & Ter \\
\hline 39 & Luisia filiformis Hook.f. & Lan san hô sợi & Epi \\
\hline 40 & Luisia ramosii Ames & San hô & Epi \\
\hline 41 & Nervilia concolor (Blume) Schltr. & Trân châu xanh & Ter \\
\hline 42 & Nervilia fordii Averyanov & Lan một lá & Ter \\
\hline 43 & Nervilia gracilis Averyanov & Diệp tâm lan & Ter \\
\hline 44 & Nervilia plicata (Andrews) Schltr. & Trân châu xếp & Ter \\
\hline 45 & Oberonia caulescens Lindl. & Móng rùa có thân & Epi \\
\hline 46 & Oberonia griffithiana Lindl. & Móng rùa griffith & Epi \\
\hline 47 & Oberonia longibracteata Lindl. & Móng rùa lá bắc dài & Epi \\
\hline 48 & Panisea uniflora Lindl. & Khúc thần một hoa & Epi \\
\hline 49 & Pelatantheria ctenoglossum Ridl. & Bạt lan trâm, Lan môi râu & Epi \\
\hline 50 & Phalaenopsis lobbii (Reichb.f) H.R.Sweet & Tục đoạn đốt & Epi \\
\hline 51 & Pinalia acervata Kuntze & Nỉ lan trắng & Epi \\
\hline 52 & Pinalia cochinchinensis (Gagnep.) Schuit. & Nỉ lan nam bộ & Epi \\
\hline 53 & Pinalia dongnaiensis (Gagnep.) S.C.Chen \& J.J.Wood & Nỉ lan đồng nai & Epi \\
\hline 54 & Pinalia floribunda Kuntze & Lan len nhiều hoa & Epi \\
\hline 55 & Pteroceras compressum (Blume) Holttum & Môi sừng & Epi \\
\hline 56 & Rhynchostylis retusa (L.) Blume & Ngọc điểm đuôi cáo & Epi \\
\hline 57 & Robiquetia succisa (Lindl.) Seidenf. \& Garay & Túi chùy thắt & Epi \\
\hline 58 & Robiquetia vietnamensis (Guillaumin) Kocyan \& Schuit. & Nhãn ngư răng & Epi \\
\hline 59 & Smitinandia micrantha (Lindl.) Holttum & Lan smitinan hoa nhỏ & Epi \\
\hline 60 & Taeniophyllum daroussinii Tixier \& Guillaumin & Căn diệp xuân lộc & Epi \\
\hline 61 & Thecostele alata (Rchb.f.) Par.\& Rchb.f. & Củ chén & Epi \\
\hline 62 & Thunia pulchra Rchb.f. & Bạch hạc nhỏ & Ter \\
\hline 63 & Vanda denisoniana Benson \& Rchb.f. & Mỹ dung dạ hương & Epi \\
\hline 64 & Vanda dives (Rchb.f.) L.M.Gardiner & Nhụy sừng trắng & Epi \\
\hline
\end{tabular}

Ghi chú: Epi: Phong lan, Lit: Thạch lan, Ter: Địa lan, *Loài bổ sung cho hệ thưc vật Việt Nam.

Họ Lan (Orchidaceae) ở Nam Bộ khá đa dạng và phong phú với 324 loài, chiếm $36,1 \%$ tổng số loài lan hiện có ở Việt Nam (897 loài) (Averyanov \& Averyanova, 2013). Các chi có số lượng loài nhiều nhất ở vùng nghiên cứu gồm: chi Hoàng thảo (Dendrobium) có 60 loài, chiếm $18,5 \%$ tổng số loài của họ Lan hiện có ở vùng nghiên cứu; kế đến là chi Cầu diệp (Bulbophyllum) có 32 loài, chiếm 9,9\%; tiếp theo là chi Móng rùa (Oberonia) và chi Thanh đạm (Coelogyne) mỗi chi có 14 loài, chiếm 4,3\%; chi Mật khẩu (Cleisostoma) có 13 loài, chiếm 4,0\%; chi Bầu rượu (Calanthe) có 9 loài, chiếm 2,8\%; và sau cùng là các chi Nhẵn diệp (Liparis), Lụi mơ (Luisia) và Nỉ lan (Pinalia) mỗi chi có 8 loài, chiếm 2,5\%. Đặc biệt trong đó có một số loài bổ sung cho hệ thực vật Việt Nam từ Nam Bộ trong thời gian gần đây như: Lan hoại sinh (Didymoplexis pallens Griff.) được phát hiện từ Vườn Quốc gia Cát Tiên và các loài Vệ lan nhiều hoa (Appendicula floribunda (Schltr.) Schltr.), Cầu diệp (Bulbophyllum physocoryphum Seidenf.), Cầu diệp lá nhỏ (Bulbophyllum tenuifolium (Blume) Lindl.), Thạch mộc ria môi rộng (Dendrobium comatum (Blume) Lindl.), Nhẵn diệp đen đỏ (Liparis atrosanguinea Ridl.), Nhẵn diệp (Liparis elegans Lindl.), Móng rùa Griffith (Oberonia griffithiana Lindl.) được phát hiện từ Vườn Quốc gia Phú Quốc (Vuong et al., 2018, 2019a, 2019b).

\section{3. Đa dạng về dạng sống}

Dạng sống của các loài thuộc họ Lan (Orchidaceae) ở Nam Bộ rất đa dạng, phân bố ở nhiều dạng sinh cảnh khác nhau, một loài có thể có một hoặc hai dạng sống khác nhau (Bảng 2). Nhóm dạng sống có số lượng loài nhiều nhất là Phong lan (Epi) với 247 loài, chiếm 76,2\% tổng số loài trong vùng nghiên cứu, nhóm này thường sống bám vào các cây gỗ lớn trong các rừng thường xanh ẩm; kế đến là nhóm Địa lan (Ter) có 60 loài, chiếm 18,5\%, nhóm này thường mọc trên đất có tầng thảm mục ẩm hoặc đất thịt dưới táng rừng; kém đa dạng nhất là nhóm vừa Phong lan (Epi) và Địa lan (Ter) chỉ có 2 loài, chiếm $0,6 \%$. Như vậy, nhóm Phong lan (Epi) chiếm tỷ lệ cao nhất $(76,2 \%)$ tổng số loài trong số các dạng sống hiện có của họ Lan ở vùng nghiên cứu, góp phần làm tăng tính đa dạng cho hệ thực vật ở Nam Bộ nói riêng và cả Việt Nam nói chung. 
Bảng 2. Thống kê số lượng loài thuộc các nhóm dạng sống của họ Lan (Orchidaceae)

\begin{tabular}{clcc}
\hline STT & Nhóm dạng sống & Số lượng loài & Tỷ lệ (\%) \\
\hline 1 & Phong lan (Epi) & 247 & 76,2 \\
2 & Địa lan (Ter) & 60 & 18,5 \\
3 & Lan hoại sinh (Sap) & 4 & 1,2 \\
4 & Thạch lan (Lit) và Phong lan (Epi) & 8 & 2,5 \\
5 & Thạch lan (Lit) và Địa lan (Ter) & 3 & 0,9 \\
6 & Phong lan (Epi) và Địa lan (Ter) & 2 & 0,6 \\
\hline & Tổng cộng & 324 & 100 \\
\hline
\end{tabular}

\section{4. Đa dạng về nguồn gen quý hiếm}

Việc xác định các loài lan nguy cấp đóng một vai trò vô cùng quan trọng trong công tác bảo tồn nguồn gen và phát triển bền vững nguồn tài nguyên đặc biệt có giá trị này. Từ kết quả nghiên cứu, có 10 loài lan (chiếm 3,1\% tổng số loài) ở Nam Bộ có giá trị bảo tồn theo Sách đỏ Việt Nam - Phần Thực vật (Bộ Khoa học và Công nghệ, 2007), trong đó có 8 loài được xếp ở thứ hạng Nguy cấp (EN) là Xích hủ thân mập (Agrostophyllum planicaule), Kim điệp (Dendrobium chrysotoxum), Ngọc vạn pha lê (Dendrobium crystallinum), Thủy tiên tua (Dendrobium harveyanum), Nhất điển hoàng (Dendrobium heterocarpum), Thạch mộc
(Dendrobium nobile), Cánh sét (Dendrobium ochraceum), Nỉ lan Đồng Nai (Pinalia dongnaiensis) và 2 loài được xếp ở thứ hạng Sẽ nguy cấp (VU) là Nhất điểm hồng (Dendrobium draconis), Thủy tiên trắng (Dendrobium farmeri), đây là những loài có vùng phân bố hẹp nhưng thường bị tác động về môi trường sống và luôn bị khai thác vì mục đích thương mại. Theo Nghị định 06 của Chính phủ, vùng nghiên cứu có 1 loài là Vân hài (Paphiopedilum callosum) được xếp trong nhóm IA- nhóm nghiêm cấm khai thác, sử dụng vì mục đích thương mại, và các loài còn lại thuộc nhóm IIA theo Nghị định này. Còn theo CITES thì loài Vân hài (Paphiopedilum callosum) nằm trong phụ lục $\mathrm{I}$ và 323 loài nằm trong phụ lục II của công ước này.

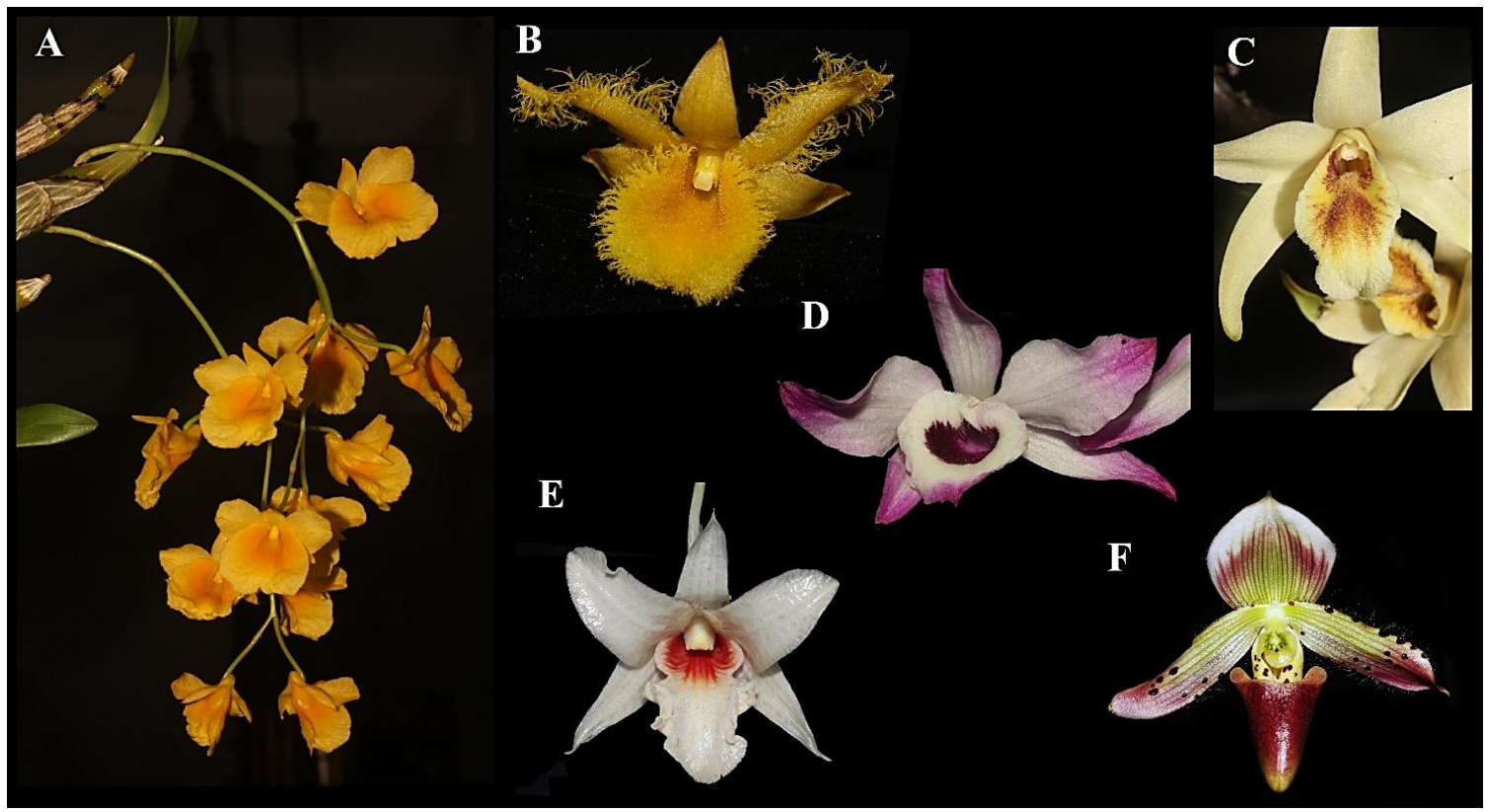

Hình 2. Một số loài lan quý hiếm trong vùng nghiên cứu

A. Dendrobium chrysotoxum Lindl.; B. Dendrobium harveyanum Reichb.f.; C. Dendrobium heterocarpum Lindl.; D. Dendrobium nobile Lindl.; E. Dendrobium draconis Reichb.f.; F. Paphiopedilum callosum (Reichb. f.) Stein (ảnh chup bởi Truong Bá Vuơng) 


\section{5. Đa dạng về giá trị sử dụng}

Đa số các loài trong họ Lan ở Nam Bộ đều có giá trị kinh tế và thương mại, được sử dụng làm cảnh, chúng thường cho màu sắc đẹp và hương thơm. Kết quả nghiên cứu cũng đã xác định được 22 loài (chiếm $6,8 \%$ tổng số loài) có giá trị dược liệu gồm: A cam sóng (Acampe carinata), A cam cúng (Acampe rigida), Tổ yến Java (Acriopsis liliifolia), Giáng huoong (Aerides falcata), Vệ lan móng (Appendicula cornuta), Lan sậy (Arundina graminifolia), Cầu diệp thom (Bulbophyllum odoratissimum), Kiều lan xếp ba (Calanthe triplicata), Đoạn kiếm lô hội (Cymbidium aloifolium), Thanh ngoc (Cymbidium ensifolium), Thach hộc lá guoom (Dendrobium acinaciforme), Hồng cầu (Dendrobium aduncum), Tuyết mai (Dendrobium crumenatum), Lan ý thảo (Dendrobium gratiosissimum), Hoàng thảo (Dendrobium nobile), Hà biện luõi đỏ (Habenaria rhodocheila), Lan một lá (Nervilia fordii), Bạch phurọng (Pecteilis susannae), Tuc đoạn kế (Pholidota articulata), Tuc đoạn kết hơp (Pholidota imbricata), Ngọc điểm đuôi cáo (Rhynchostylis retusa) và Lan đất bông ngắn (Tropidia curculigoides). Đáng chú ý, là các loài Tổ yến Java (Acriopsis liliifolia), Vẹ lan móng (Appendicula cornuta), Tuyết mai (Dendrobium crumenatum) và Lan đất bông ngắn (Tropidia curculigoides) bi người dân thu hái nhiều cho muc đích làm thuốc để chũa các bệnh nhu sốt, đau tai, dịch tả và sốt rét; còn các loài Giáng huoong (Aerides falcata), Đoạn kiếm lô họi (Cymbidium aloifolium), Thanh ngọ (Cymbidium ensifolium), Lan ý thảo (Dendrobium gratiosissimum), Hoàng thảo (Dendrobium nobile) và Ngọc điểm đuôi cáo (Rhynchostylis retusa) bị khai thác cho muc đích thuoong mai do có hoa đẹp, thơm, to và cưm hoa dài mang nhiều hoa. Do đó, cần có chính sách ưu tiên bảo tồn và phát triển bềnh vũng để tránh mất đi nguồn tài nguyên qui giá này ơ hiện tại và trong tuoong lai.

\section{KẾT LUẬN}

Kết quả nghiên cứu đã xác định được họ Lan (Orchidaceae) ở Nam Bộ có 324 loài thuộc 84 chi. Trong đó, tất cả các loài đều có giá trị làm cảnh, 22 loài có giá trị dược liệu, 10 loài trong Sách đỏ Việt Nam - Phần Thực vật (Bộ Khoa học và Công nghệ, 2007), 1 loài trong phụ lục IA và 323 loài trong phụ lục IIA của Nghị định 06/2019/NĐ-CP (Chính phủ Việt Nam, 2019), 1 loài trong phụ lục I và 323 loài trong phụ lục II của CITES.

Dạng sống của các loài thuộc họ Lan (Orchidaceae) được chia làm 6 nhóm gồm: Phong lan (Epi) có 247 loài, Địa lan (Ter) có 60 loài, Lan hoại sinh (Sap) có 4 loài, Thạch lan (Lit) và Phong lan (Epi) có 8 loài, Thạch lan (Lit) và Địa lan (Ter) có 3 loài, Phong lan (Epi) và Địa lan (Ter) có 2 loài.

Ghi nhận mới 1 loài là Hoàng thảo indragiri (Dendrobium indragiriense Schltr.) cho hệ thực vật Việt Nam, và bổ sung 64 loài cho họ Lan trong hệ thực vật Nam Bộ.

\section{LỜI CẢM ƠN}

Nghiên cứu này được tài trợ bởi Trường Đại học Thủ Dầu Một với đề tài có mã số 536/HĐNCKHPTCN tháng 12/2019. Các tác giả xin chân thành cảm ơn.

\section{TÀI LIỆU THAM KHẢO}

Averyanov, L., Cribb, P.J., Phan, K.L. \& Nguyen, T.H. (2003). Slipper Orchids of Vietnam: with an Introduction to the Flora of Vietnam. Kew. Royal Botanic Gardens.

Averyanov, L. and Averyanova, A.L. (2003). Updated Checklist of the Orchids of Vietnam. Vietnam National University Publishing House.

Averyanov, L. (2013). The Orchids Of Vietnam Illustrated Survey, Part 4. Subfamily Epidendroideae. Turczaninowia, pp.5-163.

Bộ Khoa học và Công nghệ (2007). Sách Đỏ Việt Nam - Phần thưc vật. Nhà xuất bản Khoa học và Công Nghệ. Hà Nội, trang 399-478.

Chính phủ Việt Nam (2019). Nghị định về Quản lý thực vật rừng, động vật rừng nguy cấp, quý, hiếm và thực thi Công ước về buôn bán quốc tế các loài động vật, thực vật hoang dã nguy cấp (Số 06/2019/NĐ-CP).

http://vanban.chinhphu.vn/portal/page/portal/chi nhphu/hethongvanban?class_id=1\&_page $=1 \& \mathrm{~m}$ ode=detail\&document_id $=196022$

CITES (2019). Appendices I, II \& III. https://cites.org/sites/default/files/eng/app/2019/ E-Appendices-2019-11-26.pdf

Cribb, P. (1998). The Genus Paphiopedilum. Royal Botanic Gardens Kew. London.

Dương Đức Huyến (2007). Thưc vật chí Việt Nam (Họ Lan-Orchidaceae). Nhà xuất bản Khoa học và Kỹ thuật. Hà Nội.

Đặng Văn Sơn (2012). Họ Quao (Bignoniaceae Juss. 1789) trong hệ thực vật Nam bộ Việt Nam. Tạp chí Sinh hoc, 34 (3SE): 40-50.

Đặng Văn Sơn, Trương Bá Vương, Nguyễn Thị Mai Hương, Hoàng Nghĩa Sơn, Mai Trường, Nguyễn Hồng Quân và Lê Minh Dũng (2017). Đa dạng họ Lan (Orchidaceae) ở Vườn Quốc gia Phú Quốc, tỉnh Kiên Giang. Tạp chi Khoa học và Công nghệ Việt Nam, 12 (12): 24-31. 
Đỗ Tất Lợi (2009). Nhũng cây thuốc và vị thuốc Việt Nam. Nhà xuất bản Y học. Hà Nội.

Gagnepain, F and Guillaumin, A. (1934). Orchidaceae \& Apostasiaceae. In H. Lecomte (ed.), Flore Générale de l'Indochine, Vol 6 (pp.142-647). Mason et Cie, Paris.

Karthigeyan, K., Jayanthi, J., Sumathi, R. \& Jalal J.S. (2014). A review of the orchid diversity of Andaman \& Nicobar Islands, India. Richardiana, $15,9-85$.

Lê Xuân Ái \& Trần Đình Huệ (2013). Bảo tồn tài nguyên đa dạng sinh học cho sự phát triển bền vững Côn Đảo. Trong Trần Minh Hợi \& Nguyễn Văn Sinh (Chủ biên), Báo cáo Hội nghị toàn quốc về Sinh thái và Tài nguyên sinh vật lần 5 (trang 353-359). Nhà xuất bản Nộng nghiệp, Hà Nội.

Lưu Hồng Trường, Võ Văn Sung, Vũ Ngọc Quang, Lê Bi, Nguyễn Quốc Đạt, Đinh Nhật Lâm, Nguyễn Lê Xuân Bách, Ngô Sinh Khung, Lê Văn Sơn, Nguyễn Bá Xuân và Nguyễn Văn Quyết (2012). Điều tra, giám sát các loài Thục vật (Dầu cát, Sến, Gõ đơ), khảo sát và giám sát vùng phân bố của 3 kiểu sinh cảnh quan trọng và xây dưng bộ tiêu bản thục vật của Khu BTTN Bình Châu-Phước Bưu. Báo cáo kỹ thuật.

Nguyễn Tiến Bân, L.V. Averyanov \& Dương Đức Huyến (2005). Orchidaceae Juss. 1789 - Họ Lan. Trong Nguyễn Tiến Bân (chủ biên). Danh lục các loài thực vật Việt Nam, tập 3 (trang 512666). Nhà xuất bản Nông nghiệp. Hà Nội.

Nguyễn Thiện Tịch (2001). Lan Việt Nam, quyển 1. Nhà xuất bản Nông nghiệp. Thành phố Hồ Chí Minh.

Phạm Hoàng Hộ (2003). Cây cỏ Việt Nam, quyển 3. Nhà xuất bản Trẻ. Thành phố Hồ Chí Minh, trang 760-968.

Phạm Hoàng Hộ (2006). Cây có vị thuốc ở Việt Nam. Nhà xuất bản Trẻ. Thành phố Hồ Chí Minh, trang 649-654.

Phân Viện điều tra quy hoạch rừng Nam Bộ (SubFIPI) (2009). Điều tra xây dựng danh lục và tiêu bản thực vật rùng ở Khu bảo tồn thiên nhiên và Di tích Vĩnh Củu, tỉnh Đồng Nai. Báo cáo khoa học.

Phân Viện điều tra quy hoạch rừng Nam Bộ (SubFIPI) (2010). Điều tra bồ sung danh luc thực vật và thảm thực vật rùng VQG Cát Tiên Chuoong trình Quy hoạch bảo tồn và phát triển bền vũng Vuờn quốc gia Cát Tiên, giai đoạn 2011-2020. Báo cáo khoa học.

Sterling, E.J., Hurley, M.M. and L.D.Minh (2007). Lịch sử tụ nhiên của Việt Nam. Yale University Press New Haven and London, trang 277-333.

Trần Hợp (1998). Phong lan Việt Nam. Nhà xuất bản Nông nghiệp. Thành phố Hồ Chí Minh.

Viện Sinh học nhiệt đới (ITB) (2010a). Điều tra, giám sát một số loài và sinh cảnh quan trọng tại VQG Bù Gia Mập. Báo cáo khoa học.

Viện Sinh học nhiệt đới (ITB) (2010b). Điều tra đánh giá hiện trạng tài nguyên động thục vật Vuoờn Quốc gia Lò Gò - Xa Mát. Báo cáo khoa học.

Võ Văn Chi (2012). Tù điển cây thuốc Việt Nam, tập 1,2 . Nhà xuất bản Y học. Hà Nội.

Vuong, T.B., Cootes, J., Tam, T.Q. \& Son, D.V. (2018). Liparis atrosanguinea Ridl. (Orchidaceae) - A New Record for Vietnam in Phu Quoc Park, Kien Giang Province. Die Orchidee, 4(1): 1-6.

Vuong, T.B., Dung, L.M., Quan, N.H., Hau, N.P. \& Cootes J. (2019a). New records of three minature Orchids from Phu Quoc National Park, Vietam. Die Orchidee, 5(5): 35-43.

Vuong, T.B., Ormerod, P., Cootes, J. \& Dung, L.M. (2019b). New records for the Orchid Flora of Vietnam from Phu Quoc National Park. Malesian Orchid Jounrlal, 23: 113-119.

The Plant List (2013). Version 1.1. Published on the Internet; http://www.theplantlist.org/ (Accesses: 09/10/2020).

https://wcsp.science.kew.org (Accesses: 12/10/2020). 